\title{
家亘における新突然変異 “過剩半月紋退化腹肢”遺伝子
}

\author{
蒲生卓磨
}

農林省暻糸試験場青種部

Received February 8, 1965

\section{A NEW EXTRA-CRESCENT GENE $\left(E^{D l}\right)$ CAUSING DEGENERATION OF ABDOMINAL LEGS IN THE SILKWORM}

\author{
TAKUMA GAMO
}

Section of Breeding, Sericultural Experiment station, Hino, Tokyo

\section{Résumé}

In this paper, the author described manifestation and genetical behavior of an extra-crescent gene discovered from a commercial race of silkworm, and discussed about its genetical relationship with $E$ pseudo-alleles on the 6 th chromosome.

1. Homozygotes for this character have a pair of extra-crescent markings on the 6 th segment, no star-spots on the 8th segment, and no abdominal legs at the 6 th segment (Fig. 1). In heterozygotes, manifestation of the extra markings on the 6 th segment is incomplete and variable as shown in Fig. 2. The penetrance and manifestation of $E^{D l}$ gene are affected by some genetical constitution of strains.

2. This mutant reveals no abnormalities of sexual organs and has no lethal effects on the embryo.

3. No abdominal legs on the 6 th segment is complete recessive to normal and the extra-crescent markings on the same segment are incompletely dominant. Both the characters, however, are controlled by a single gene.

4. This gene is located in the $E$ pseudo-allelic region on the 6 th chromosome, and symbolized as $E^{D l}$ : extra-crescent and degenerated abdominal legs.

5. The recombination value obtained between $E^{D l}$ and $E^{H}$ genes was $0.32 \pm 0.09 \%$.

6. $E^{D l}+1+E^{N}$ individuals have no abdominal legs on the 6 th segment. This fact seems to show that the locus of $E^{D l}$ falls partly on the site of $E^{N}$. And taking the results of ltikawa (1952 b, 1957), Tsujita (1955) and Tsujita et al. (1959 b) into consideration, it is assumed that the arrangement of genes at the $E$ region is as follows: $E^{H} E^{N} E^{D l} E^{C a} E^{K p} E^{N c} E^{C d}$.

1962年晚秋虫期に飼育した農林委㢪性状調查の品種「昭光 $\times$ 栄華」から, 幼虫の第 6 環節要背線に小さな過㮃 斑紋を有する個体が数\%の割合で見いだされた。これを相互交配して翌1963年春寔期に飼育したとてろ, 第 6 環 節に過剩半月紋を有する個体が多数現われ，そのうち第 8 環節の星絞と第 6 環節の腹肢あるいはその鉤爪を欠く ものは全体の約 $25 \%$ であった (Fig. 1).

家虫において半月粒を過剩に生ずるものとしては既に第 6 染色体の $E$ 偽対立遺伝子群に属する多くの遺伝子 が知られている（佐々木 1930，橋本 1941，有賀ほか 1951，市川 1952，高崎 1952，辻田・坂口 1959 bなど）. 


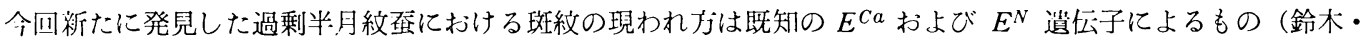
太田 1930, 市川 1943）とよく似ているが，乙れらの遗伝子が腹肢の欠如を学かないてとは顕著な相逢点であ る.また，腹肢を欠如するものとしては边旧・垅回（1959 a , b ）の $E^{T c}$ 遺伝子があるが， $E^{T c}$ では 4 対の腹

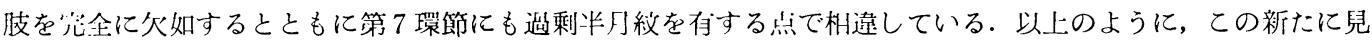
いだされた過剩半月紋至注 $E$ 偽対记遺伝了群に属する既知の変買型に類似するが，発現の様相を多少異にするの で，新らしい遗伝子によるものではないかと推察された：そてでての形質の遗伝的行動および多面発現の程度を 調べるととに，E偽対立遗伝子群に属する2・3の遺伝子との遺伝的関係を調べたところ，E群に属する新ら しい突然変異であることが判明した。乙れを過利粠月紋退化腹肢と称し， $E^{D l}$ (Extra crescents and degenerated abdominal legs) なる遗伝子䛉铮を附すととにする。

本文に入るに先立ち，教示，校閲をたまわった農林蛋試，漓見义犬博七と大牛秀大氏および貴重な系統を患与 下された宸林腽試, 広部達道博士に厚く御礼申し、上げる。

\section{材料および実験方法}

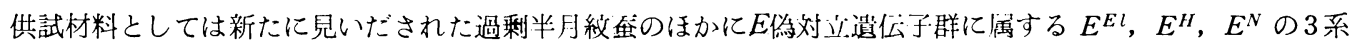

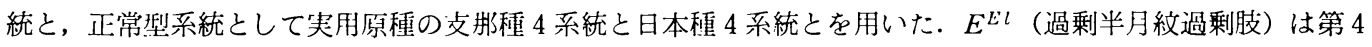
環節に過剩半月紋を発現するとともに，第 4 と第 5 環節とに過剩の小形腹肢を生ずるものである． $E^{H}(\mathrm{H}$ 過剩半 月紋）は第 4 環節に過剩半月紋を生ずるが，腹肢に関しては正常なものである．また， $E^{N}$ (新重い形) は第 6 環節に過剩半月紋を発現し，第 8 環節の星紋を欠くが，さらに多くの過剩半月紋を有する個体を生じ，その現わ れ方には変異の多いものである.

まず，突然変異個体の特徵を明らか任するため，過剩半月紋の形状の究全なもの（560 型と称す）と不究全な もの $\left(5 \dot{6} 8\right.$ 型* $\left.^{*}\right)$ とについて交配を行ない，斑紋および腹肢の現れ方を調べるとともに，産畉数，受精率，稃化率

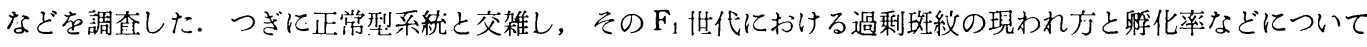

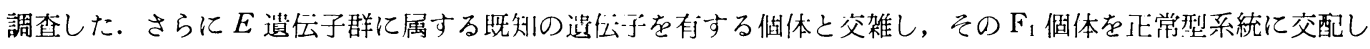

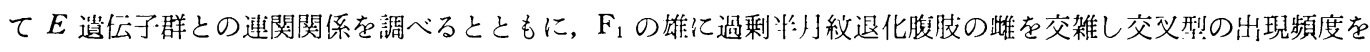
調藏した。

\section{実 験 結 果}

\section{1. 過剩半月紋寔の相互交配}

過剩半月紋の完全なもの（560型）「汇沁の交配では，560型のみを生じ，しかもその大半が第 6 環節の腹肢ある いはその鈎爪を欠如するものであった（Table 1)。一jj，560型と不完全な過剩玟紋を有する 5688 型（腹肢は 正常）との交配では， $560 \times 568$ （a）区を除けば，総て 560 型が約 $50 \%$ と68型および58型（正常型）とを分離し た. $5 \dot{6} 8$ 型として表示したものには Fig. 2 亿示すように半月紋の大きさに種々の程度のものがあり, 連続的変異

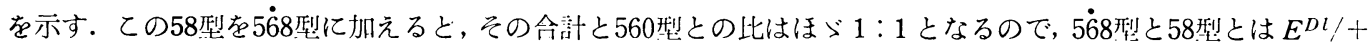
であり，560型あるいは $5 \dot{6} 8$ 型を示し第 6 環節の腹肢あるいはちの鈎爪を欠くものは $E^{D l} / E^{D l}$ であろうとみるこ

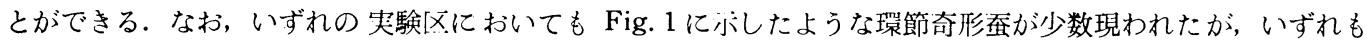
$E^{D l}$ homo 個体にのみ認められた．560型の相互父配による越年卵在翌春飼育した蛾区（d）にはさらに第 7 環 節に不完全な斑紋を有する5670型が現われたが，乙れらの個体には第 7 罢節における第 2 腹肢をも欠如するもの が少数含まれていた，そてで，てれらの次代における発現様式を調べたとてろ，Table 2 に示すように5670型

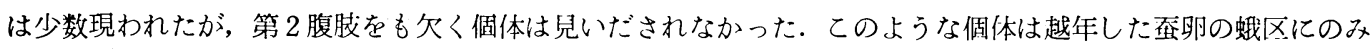
現われ，しかも遺伝性を示さなかったてとからみて，発生過程にわける一畹的な異常により!1:じたものと判断さ れる.

\footnotetext{
* $\dot{6}$ は第 6 環節にわける半月絞の形状が不充念なととを示す.
} 
Table 1. Manifestation of $E^{\prime l}$ gene and occurrence of segmental malformation

\begin{tabular}{|c|c|c|c|c|c|c|c|c|c|c|c|}
\hline \multicolumn{3}{|c|}{ Marking } & \multirow{2}{*}{$\frac{58}{+}$} & \multicolumn{2}{|c|}{$5 \dot{6} 8$} & \multicolumn{2}{|c|}{560} & \multirow{2}{*}{$\frac{56 \dot{70}}{D l}$} & \multirow{2}{*}{ Total } & \multirow{2}{*}{$\begin{array}{l}\text { Segmental } \\
\text { malformation }\end{array}$} & \multirow{2}{*}{$\begin{array}{l}\text { Eggs used } \\
\text { for rearing }\end{array}$} \\
\hline & & Leg & & + & $D l$ & + & $D l$ & & & & \\
\hline $5 \dot{6} 8$ & $\times 5 \dot{6} 8$ & & 172 & 131 & 3 & 5 & 102 & 0 & 413 & $0.72 \%$ & over-wintered \\
\hline 560 & $\begin{array}{l}\times 560 \\
11 \\
" 1 \\
" 1\end{array}$ & $\begin{array}{l}\text { (a) } \\
\text { (b ) } \\
\text { (c ) } \\
\text { (d) }\end{array}$ & $\begin{array}{l}0 \\
0 \\
0 \\
0\end{array}$ & $\begin{array}{r}0 \\
0 \\
0 \\
37\end{array}$ & $\begin{array}{l}0 \\
0 \\
0 \\
1\end{array}$ & $\begin{array}{r}33 \\
0 \\
23 \\
6\end{array}$ & $\begin{array}{l}440 \\
436 \\
483 \\
231\end{array}$ & $\begin{array}{c}0 \\
0 \\
0 \\
15^{*}\end{array}$ & $\begin{array}{l}473 \\
436 \\
506 \\
290\end{array}$ & $\begin{array}{l}4.33 \\
2.06 \\
1.58 \\
3.44\end{array}$ & $\begin{array}{l}\text { artificial } \\
\text { non-diapause } \\
\text { over-wintered }\end{array}$ \\
\hline & $\begin{array}{l}\times 5 \dot{6} 8 \\
\text { "I }\end{array}$ & $\begin{array}{l}\text { (a) } \\
\text { (b) }\end{array}$ & $\begin{array}{r}0 \\
16\end{array}$ & $\begin{array}{r}0 \\
277\end{array}$ & $\begin{array}{r}74 \\
0\end{array}$ & $\begin{array}{l}0 \\
0\end{array}$ & $\begin{array}{l}435 \\
242\end{array}$ & $\begin{array}{l}0 \\
0\end{array}$ & $\begin{array}{l}509 \\
535\end{array}$ & $\begin{array}{l}1.38 \\
1.49\end{array}$ & artificial \\
\hline $5 \dot{6} 8$ & $\begin{array}{l}\times 560 \\
\text { "I }\end{array}$ & $\begin{array}{l}\text { (a) } \\
\text { (b) }\end{array}$ & $\begin{array}{r}9 \\
155\end{array}$ & $\begin{array}{l}271 \\
155\end{array}$ & $\begin{array}{l}0 \\
0\end{array}$ & $\begin{array}{r}38 \\
0\end{array}$ & $\begin{array}{l}227 \\
308\end{array}$ & $\begin{array}{l}0 \\
0\end{array}$ & $\begin{array}{l}545 \\
618\end{array}$ & $0 . \overline{81}$ & non-diapause \\
\hline
\end{tabular}

$5 \dot{6} 8$ : incomplete extra-crescent markings on the 6 th segment

560: complete extra-crescent markings on the 6 th segment and no star-markings on the 8 th segment

58: normal type of marking

$D l$ : degeneration of the 1 st abdominal legs on the 6 th segment

*: larvae with degenerated legs on both the 1 st and 2 nd abdominal segments are included.

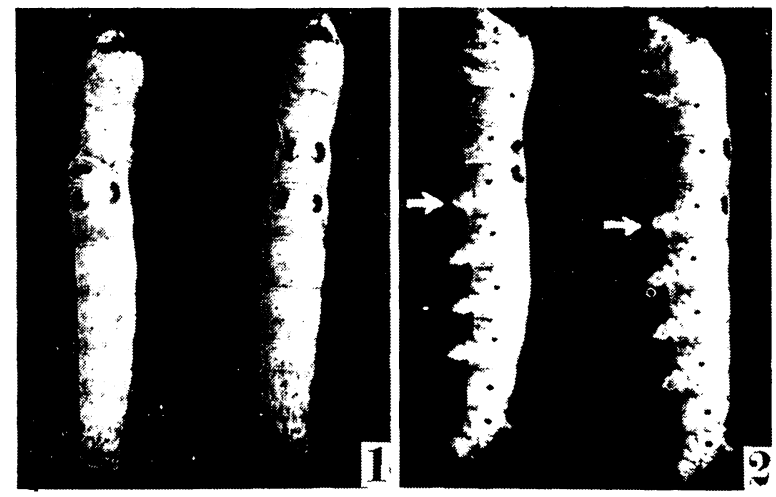

Fig. 1. Phenotypic effects in $E^{D l}$ homozygotes.

Left: segmental malformation. Right: usual type.

Allows show the degeneration of abdominal legs.

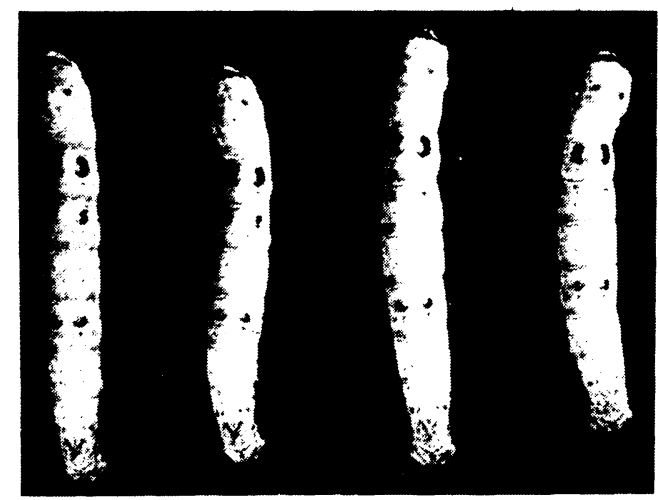

Fig. 2. Variation of extra markings on the 6 th segment in $E^{D l}$ heterozygotes. 
Table 2. Manifestation of $E^{D l}$ gene in the progeny of 5670 parents (degeneration of both the 1 st and 2 nd abdominal legs)

\begin{tabular}{lrrr}
\multicolumn{1}{c}{ Leg } & Marking & & \multirow{2}{*}{ Total } \\
\cline { 2 - 4 } & 560 & $56 \dot{0}$ & 0 \\
\hline Normal & 1 & 3 & 1 \\
Degeneration of the 1 st & 471 & 0 & 474 \\
Degeneration of the 1 st and 2nd & 0 & 3 & 475 \\
\hline
\end{tabular}

以上のように，最初見いだされた $5 \dot{6} 8$ 型は $E^{D l}$ 造伝子の hetero 型であったととが判るが，この個体が日本程 と交那種との交雑種（ $F_{1} ）$ から発兒されたてとからみて，原種の炤光あるいは栄華の一方に既に存在していたて とが想像される。しかしながら，1963年春虫期の調査ではどちらの原種（会社の採種による）にも $E^{D l}$ 個体は 見いだされなかった。

\section{2. 正嫦型系統との交雑}

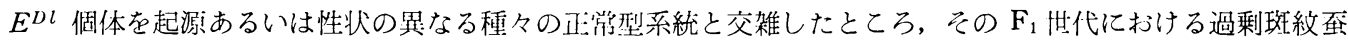
の出現率は Table 3 に示すように交配した相手の系統により顕著に相違した。すなわち, 少115, 支124, たか ね，麗玉と交雑した埸合にはいずれも低い出現率を示したのに対して，郡宝，大草，しなの，日 124 と交雑した 場合高い出現率を示した。 また，支 115 との交雑 $\mathrm{F}_{1}$ 個体を $E^{D l}$ 系統の 560 型に帍し交雑した埸合にもその出现

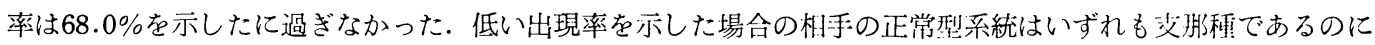
対し，高い出現率を示した系統はいずれも日本種である.

Table 3. Manifestation and penetrance of $E^{D l}$ gene

\begin{tabular}{|c|c|c|c|c|c|c|}
\hline \multirow{2}{*}{ Cross } & \multicolumn{2}{|c|}{ Normal leg } & \multirow{2}{*}{$\frac{D l}{560}$} & \multirow{2}{*}{ Total } & \multicolumn{2}{|c|}{ Penetrance } \\
\hline & 58 & $5 \dot{6} 8$ & & & Expected & Experimented \\
\hline$C 115 \times 560$ & 387 & 0 & 0 & 387 & $100 \%$ & $0.0 \%$ \\
\hline$C 115 \times 5 \dot{6} 8$ & 458 & 16 & 0 & 474 & 50 & 3.4 \\
\hline $560 \times(C 115 \times 5 \dot{6} 8)$ & 133 & 68 & 215 & 416 & 100 & 68.0 \\
\hline$C 124 \times 560$ & 252 & 25 & 0 & 277 & 100 & 9.0 \\
\hline Takane $\times 560$ & 215 & 4 & 0 & 219 & 100 & 1.8 \\
\hline Reigyoku $\times 560$ & 70 & 7 & 0 & 77 & 100 & 9.9 \\
\hline Gunpô $\times 560$ & 90 & 297 & 0 & 387 & 100 & 76.7 \\
\hline $560 \times \hat{O} k u s a$ & 123 & 384 & 0 & 507 & 100 & 75.7 \\
\hline$\hat{O} k u s a \times 560$ & 40 & 513 & 0 & 553 & 100 & 92.8 \\
\hline $560 \times$ Shinano & 27 & 376 & 0 & 402 & 100 & 93.3 \\
\hline $5 \dot{6} 8 \times$ Shinano & 217 & 146 & 0 & 363 & 50 & 40.2 \\
\hline$N 124 \times 560$ & 41 & 297 & 0 & 338 & 100 & 87.8 \\
\hline
\end{tabular}

* Italic letters: names of normol strain

$E^{D l}$ 遗伝子が過剩玟紋の発現に関して完全優性として行動するならば 560 型 $\left(E^{D l} / E^{D l}\right)$ との交雑区では理諭 的には100\%の浸透率 (penetrance) を示し，568型（EDl/t）との交雑では $50 \%$ 值を示すはずであるが，い ずれの場合もこれらより低い值を示した。しかしながら，日本種と交雑した場合には支那種との交雑の場合より も高い值を示したので，日本種は一般に $E^{D l}$ 遺伝子の浸透度を高くするように働らく遺伝子構成を有するもの 
と解される.したがって， $E^{D l}$ 遺伝子は過剩斑紋の発現に関しては不完全優性に行動し，hetero 個体にわける 浸透率は遗伝的背景により変動するものといえる.

3. 産畉数, 受精率および睬化率

上述の実験に用いた蛾区の寔卵について孵化調査を行なった絬果, 産卵数, 受精率および瞬化率には何らの異 常は認められなかった (Table 4)。

Table 4. Effect of $E^{D l}$ gene on the fecundity and hatchability

\begin{tabular}{|c|c|c|c|c|c|c|c|}
\hline \multirow{3}{*}{ Cross } & \multirow{3}{*}{$\begin{array}{l}\text { Number of } \\
\text { batches } \\
\text { examined }\end{array}$} & \multicolumn{4}{|c|}{ Number of eggs laid } & \multirow{3}{*}{ Total } & \multirow{3}{*}{$\begin{array}{l}\text { Hatchability } \\
\text { for fertilized } \\
\text { eggs }\end{array}$} \\
\hline & & \multirow{2}{*}{ Hatched } & \multicolumn{2}{|c|}{ Dead } & \multirow{2}{*}{$\begin{array}{l}\text { Non- } \\
\text { fertilized }\end{array}$} & & \\
\hline & & & Early & Late & & & \\
\hline $560 \times 560$ & 5 & 3430 & 45 & 176 & 16 & 3667 & $93.95 \%$ \\
\hline $560 \times 5 \dot{6} 8$ & 3 & 1722 & 78 & 78 & 13 & 1891 & 91.70 \\
\hline $5 \dot{6} 8 \times 560$ & 3 & 1853 & 21 & 43 & 4 & 1921 & 96.67 \\
\hline$C 115 \times 560$ & 1 & 477 & 16 & 25 & 7 & 525 & 92.07 \\
\hline$C 115 \times 5 \dot{6} 8$ & 1 & 584 & 13 & 14 & 4 & 615 & 95.59 \\
\hline $560 \times$ Shinano & 1 & 523 & 3 & 50 & 0 & 576 & 90.80 \\
\hline $5 \dot{6} 8 \times$ Shinano & 1 & 583 & 0 & 11 & 0 & 594 & 98.15 \\
\hline
\end{tabular}

このことから過剩半月紋迮化腹肢遗伝子は生殖器官に対しては多面的効果を示さず，また homo 型において も致死性在有しないものといえる。なお蛹および成出の外部形態にも異常は認められなかった。

4. 座乗染色体

第 6 染色体にある $E$ 偽刘迄遗伝子群との連関関係を調べるため, $E^{H}, E^{N}$ および $E^{E l}$ 遺伝子を別々に有す る個体と交雑した.

第 4 環節に過剩半月紋を生ずる $E^{H}$ との交雑では， $\mathrm{F}_{1}$ 世代に 458 型，4568型，58型わよび56 8 型が現われたが その458型を雌にして正常型系統（艾124）と交雑したとてろ，2種の過剩半月紋遗伝子をともに有するものと考 えられる4560型は現われずに, 58型, 568型と458型とが現われた（Table 5). 交雑に用いた $E^{H}$ 俔体は hetero 型 であり， $E^{D l} /+$ 個体は前述のように表型的に正常型（58型）を現わすととがあるので， $\mathrm{F}_{1}$ 比代の 458 型と 4568 型とは $E^{H}+/+E^{D l}$ で，58型と568型とは+ +/ $+E^{D l}$ であろうと考えられる４58型倠を正常型と交雑した場合 には58型の出現数が多く, $1: 1$ の分離比を示さなかったが， $E^{H}$ と $E^{D l}$ 遗厷子とは分離して現われたので，両 遗伝子は連関関係にあるものとみることができる. 58型を $E^{D l}$ hetero 型と考えると $E^{H}$ 個体の出現率が期待 值より少ない，てれは橋本（1941）が述べているように $E^{H}$ hetero 個体が幼虫期に死亡したためとも考元られ るが，乙の場合における减虫数がそれほど多くなかったので，あるいは $E^{H} /+$ 俔体の中にも $E^{D l} /+$ 個体のよ うに 58 型の表現型をとるものがあり，そのために $E^{H}$ 個体の数が少なくなったのかもしれない.

Table 5. Cross between $E^{D l}$ and $E^{H}$ individuals

\begin{tabular}{|c|c|c|c|c|c|c|}
\hline Leg & + & + & + & + & \multirow{2}{*}{ Total } & \multirow{2}{*}{$\begin{array}{l}\chi^{2} \text { analysis of } 1: 1 \\
\text { segregation }\end{array}$} \\
\hline Marking & 458 & $45 \dot{6} 8$ & 58 & $5 \dot{6} 8$ & & \\
\hline $560\left(E^{D l}\right) \times 458\left(E^{H}\right)$ & 139 & 2 & 130 & 56 & 327 & - \\
\hline$F_{1}(458) \times \operatorname{normal}\left(58^{*}\right)$ & 240 & 0 & 192 & 110 & 542 & $0.1<\mathrm{P}<1.0 \%$ \\
\hline
\end{tabular}

* C 124 strain 
$E^{N}$ 遺伝子（560型を示し，homo 致死）を有する個体との交雑では， $F_{1}$ 世代に58型，568型と5670910型とが现 われ，5670910型は第 6 環節にわける第 1 腹肢を欠くものであった（Table 6). 交雑に用いた $E^{N}$ 個体は hetero 型であるので58型と568型とは $E^{D l}+/++て ゙, 5670910$ 型は $E^{D l}+/+E^{N}$ であろうと判断される. 前者に比べて 後者の数が少ないが, $E^{N}$ が hetero でも死にやすいものと考光るとその分離比はほぶ $1: 1$ となる. トランス 型と考元られる5670910型雌を正常型に交雑した場合には， $E^{D l}$ と $E^{N}$ 遺伝子とは $1: 1$ 亿分離して現われ，両 遺伝子をともに有するものと考光られる個体は一頭も現われなかった。したがって， $E^{D l}$ と $E^{N}$ 遺伀子とは遺伝 的に連関関係にあるものとみるととができる。

Table 6. Cross between $E^{D l}$ and $E^{N}$ individuals

\begin{tabular}{|c|c|c|c|c|c|c|c|}
\hline \multirow{2}{*}{ Cross $\quad$ Leg } & \multicolumn{3}{|c|}{+} & \multicolumn{2}{|c|}{$D l$} & \multirow{2}{*}{ Total } & \multirow{2}{*}{$\begin{array}{l}\chi^{2} \text { analysis of } 1: 1 \\
\text { segregation }\end{array}$} \\
\hline & 58 & $5 \dot{6} 8$ & 560 & 56010 & 5670910 & & \\
\hline $560\left(E^{D l} \times 560\left(E^{N}\right)\right.$ & 53 & 135 & 0 & 0 & 166 & 354 & - \\
\hline$F_{1}(5670910) \times$ normal $(58)$ & \multicolumn{2}{|c|}{88} & \multicolumn{2}{|c|}{85} & & 173 & $90>\mathrm{P}>80 \%$ \\
\hline
\end{tabular}

第 4 および第 5 環節に過剩腹肢を有し,さらに第 4 関節に過剩半月紋を生ずる $E^{E l}$ 個体との交雑では（Table 7)， $\mathrm{F}_{1}$ 世代に458型，4568型，58型と568型とが現われた．交配した $E^{E l}$ 個体は $E^{E l} /+$ であるから，458型と $45 \dot{6} 8$ 型とは $E^{D l}+/+E^{E l}$ で，他の 2 型は $E^{D l}+/++$ であろうと判断されるが，その分離比は $1: 1$ を示さな かった.しかし， $\mathrm{F}_{1}$ 世代の 4568 型を正常型に交雑した場合には，58型と458型とが $1: 1$ に現われ， $E^{D l}$ と $E^{E l}$ との間に連関関係のあるととを示している.

Table 7. Cross between $E^{D l}$ and $E^{E l}$ individuals

\begin{tabular}{|c|c|c|c|c|c|c|}
\hline \multirow{2}{*}{$\begin{array}{ll} & \text { Leg } \\
\text { Cross } & \text { Marking }\end{array}$} & \multicolumn{2}{|c|}{$4,5 S l^{*}$} & \multicolumn{2}{|c|}{+} & \multirow{2}{*}{ Total } & \multirow{2}{*}{$\begin{array}{l}\chi^{2} \text { analysis of } 1: 1 \\
\text { segregation }\end{array}$} \\
\hline & 458 & $45 \dot{6} 8$ & 58 & $5 \dot{6} 8$ & & \\
\hline $560\left(E^{D l}\right) \times 458\left(E^{E l}\right)$ & 89 & 66 & 167 & 98 & 420 & - \\
\hline$F_{1}(4568) \times$ normal $(58)$ & 212 & 0 & 212 & 0 & 424 & $\mathrm{P}=100 \%$ \\
\hline
\end{tabular}

* Supernumeraly legs on the 4 th and 5 th segments

\section{5. $E$ 遺伝子群との組換え}

新たに見いだされた過剩半月紋退化腹肢遺伝子 $\left(E^{D l}\right)$ はこのように既知の $E^{H}, E^{N}, E^{E l}$ などの $E$ 遺伀子 群と連関関係にあることが判明したが, 最近の研究により $E$ 遺伝子群に属する多くの遺伝子間で交叉の起るてと が明らかにされているので（市川 1957, 辻田 1955), 既知の $E$ 遺伝子との交雑 $\mathrm{F}_{1}$ 個体を雄に用いて $E^{D l} / E^{D l}$ 個体汇戻し交雑し，遺枟的組換光率を調へた。

まず， $E^{N}$ との交雑では $\mathrm{F}_{1}$ (トランス型）は斑紋が 5670910 型で，第 6 腹肢を欠くが (Table 6)，乙れは店 し交雑によって生ずるシス型と表現型が同一で，識別するてとができず，組換え価を求めることは不问能であっ た.

$E^{H}$ 個体との交雑では，Table 5 に亦したように $\mathrm{F}_{1}$ 世代に 4 種の表現型が現われたが，そのトランス型雄を $E^{D l} / E^{D l}$ 個体に戻し交雑すると，458型，4568型と560型の他に組換え型と考えられる58型，568型と4560型とが 少数現われた (Table 8).58型と568型とは組換えにより生じた $E^{D l} /+$ で, 4560 型（第 1 腹肢欠如）は同じく 組換えにより生じた $E^{H} E^{D l} /+E^{D l}$ (シス型) と考えられるので，てれらの出現数をるとに計算すると， $E^{D l}$ 一 $E^{H}$ 開の組換元率は $0.32 \pm 0.09 \%$ となる. 
Table 8. Segregation of characters in the $\mathrm{BF}_{1}$ generation of the cross between $E^{D l}$ and $E^{H}$ individuals

\begin{tabular}{|c|c|c|c|c|c|c|c|}
\hline Leg & + & + & + & + & + & $D l$ & \multirow{2}{*}{ Total } \\
\hline Marking & 458 & $45 \dot{6} 8$ & 560 & 58 & $5 \dot{6} 8$ & 4560 & \\
\hline$E^{D l} / E^{D l} \times E^{H}+/+E^{D l}$ & 1122 & 459 & 1839 & 4 & 2 & 5 & 3431 \\
\hline
\end{tabular}

Cross over value: $0.32 \pm 0.09 \%$

つぎに $E^{E l}$ 個体との交雑についてみると, $\mathrm{F}_{1}$ 世代にトランス型の $456 \dot{6} 8$ 型（第 4,5 環節に過剩肢）が現われ たが (Table 7)，てれを雄にして $E^{D l} / E^{D l}$ 個体へ戻し交雑すると，458型，4568型と560型の他に 58型，5668型 と4560型とが少数現われた (Table 9). 多く現われた 458 型と $45 \dot{6} 8$ 型とは $E^{H}+/+E^{D l}, 560$ 型は $E^{D l} / E^{D l}$ で, その分離はほメ゙ $1: 1$ を示した. 少数現われた 4560 型（第 4,5 環節に過剩肢）雄を再び $E^{D l} / E^{D l}$ 個体に戻し

Table 9. Segregation of characters in the $\mathrm{BF}_{1}$ generation of the cross between $E^{D l}$ and $E^{E l}$ individuals

\begin{tabular}{|c|c|c|c|c|c|c|c|}
\hline \multirow{2}{*}{$\begin{array}{cc}\text { Leg } & \text { Leg } \\
\text { Crosking }\end{array}$} & \multicolumn{2}{|c|}{$4,5 S l$} & $D l$ & + & + & $4,5 S l$ & \multirow{2}{*}{ Total } \\
\hline & 458 & $45 \dot{6} 8$ & 560 & 58 & $5 \dot{6} 8$ & 4560 & \\
\hline$E^{D l} / E^{D l} \times E^{D l}+/+E^{E l}$ & 426 & 989 & 1460 & 1 & 23 & 14 & 2913 \\
\hline
\end{tabular}

交雑して次代の検定を行なってみると極めて複雑な分離を示し， 4560 型を $E^{D l} E^{E l} / E^{D l}+$ と判定するてとは 不可能であった. したがって, Table 9 の結果から $E^{D l}-E^{E l}$ 間の組換え価を求めるてとはできなかった. て の戻し交雑で特に $E^{E l}$ 個体が多く現われたてとと，第 4 環節に過剰半月紋を生じたにもかかわらず腹肢に関し て正常な個'本が多数現われたてさは今後倹封て值するものと考えられる.

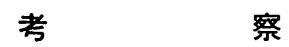

家歪の実用品種から見いだされた過剩半月紋量の遺伝的関係を調べたとてろ, 第 6 染色体のE 偽対立遺伝子群 に属する新らしい遺伝子であることが明らかとなり，乙れを過剩半月紋退化腹肢 $\left(E^{D l}\right.$; Extra-crescents and degenerated abdominal legs) 遺伝子と命名したが, 趐や生殖器官に多面的効果を示さず, homo 型が生存す る. homo 型は第 6 環節に過剩半月紋を発現するとともに第 8 環節の琵紋と第 6 環節の第 1 腹肢を欠如するのに 対して (Fig. 1)，hetero 型は第6 環節に不完全な過剰斑紋を生ずるに過ぎない (Fig. 2). この hetero 個体に おける過剩斑紋虫の発現率は遗伝的背景により変動し，100\%の浸透率（penetrance）を示すととはない. 日本 種の系統は hetero 型における過剩斑紋の浸透率および発現度（斑紋の大きさ，形状）を高めるよう働らく遣伝 子構成を有するもののようである.すなわち, $E^{D l}$ 遺伝子は腹肢の欠如に関しては少性として, 過剩斑紋の発現 に関しては不完全優性として行動する.

$E$ 偽対立遺伝子群は辻田・坂口（1959b）の研究により，多くの site り成る複合座位. (complex loci) であ ろうと考えられているが, 過剰半月紋の発見様式からみると, $E^{D l}$ 遺伝子は $E^{C a}, E^{K p}, E^{\mathrm{v}}, E^{N p}$ および $E^{M p}$ 遺伝子に近いか，あるいはこれらの site に共通する小さな site よりなるものであろうと判断されるままた，腹 肢の欠如に関しては $E^{T c}$ 遺伝子と類似するが，その作用が弱くしかも homo 個体が生存するてとから見て， $E^{D l}$ 遺伝子は $E^{T c}$ site における小さな site の変化により生じた突然変異であろうとも考えられる.さらに，第 6 環節に過剩半月紋を生ずる $E^{N}$ とのトランス型が $E^{D l}$ hetero にもかかわらず第 1 腹肢を欠如したてとからみて (Table 6)， $E^{D l}$ 遗伝子は $E^{N}$ site と部分的に共通するようにも思われる. 交配丰験の結果 $E^{D l}$ と $E^{H}$ との 
間に $0.32 \pm 0.09 \%$ の組換光価を得たが (Table 8)，辻田（1955）により $E^{H}$ と $E^{K p}$ との組換価は $0.7 \%$ であ

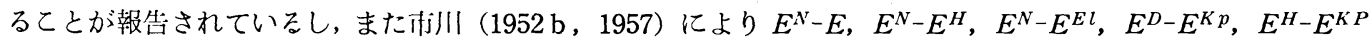
などの閒に組換光か観察されている。したがって，さらに詳細な実験を行なわない限り無理ではあるが、てれら の知見を加味して検討すると $E$ 遺伝子群における遺伝子の配列は $E^{H} \cdot E^{N} \cdot E^{D l} \cdot E^{C a} \cdot E^{K p} \cdot E^{N c} \cdot E^{G d}$ の順 になり， $E^{D l}$ 遺伝子は $E^{H}$ と $E^{C a}$ に渡る $E^{T c}$ の site における小さな site の変化によるものと推論される.

以上の上うに， $E^{D l}$ 遺伝子には hetero 型の表型が正常型と識別しにくいという不便な点もあるが, 致死作用 などの多面的効果がなく，しかも腹肢欠如という他の $E$ 遺伝子とは作用方向の異なる 遺伝子効果を示すので, $E$ 部位にわける遗伝子構成や遺伝子の相互作用と表現型との関係などを究明するには極めて 好い材料と考元ら れ, 今後の研究が期待される.

\section{要 約}

1. 奏用品種「昭光×栄華」に見いだされた過剩半月紋蚕の発現様式およびその遭伝を調べた。

2. 第 6 染色体の $E$ 偽対立遺伝子群に所属することが判明したので, てれを過郵半月紋退化腹肢 $\left(E^{D l}:\right.$ extracrescents and degenerated abdominal legs) 遺伝子と命名した.

3. hetero 型は第 6 環節に不完全な半月紋を現わし，その浸透率および発現度は遺厷的構成の影響を受ける もののようで, 正常斑紋の日本種采統と交雑した場合に高い漫透率を示した. homo 型は第 6 環節に過剰半月紋 を有するが第 8 環節の星紋わよび第 6 環節における第 1 腹肢あるいはその鈎爪を欠く.

4. 腹肢の欠如は少性であるが, 過剩半月紋の発現は不完全優性である.

5. 致死性を有せず, 雌雄生殖器官, 翅などの異常を伴なわない.

6. $E^{H}$ 遺伝子との間に $0.32 \pm 0.09 \%$ の組換え率が得られた。

7. $E^{N}$ 遺伝子とのトランス型は $E^{D l}$ hetero にもかかわらず第 1 腹肢を灭好したので， $E^{N}$ と共通の site を 有するものと推察される.

8. E部位における遺伝子の配列を考察すると, $E^{H} \cdot E^{N} \cdot E^{D l} \cdot E^{C a} \cdot E^{K p} \cdot E^{N c} \cdot E^{G d}$ の順になり, $E^{L l}$ は $E^{H}$ と $E^{C a}$ にまたがる $E^{T c}$ site にわける小さな site の変化によるものと推定される.

\section{交献}

有賀久雄ほか, 1951 家亘遺伝子の研究. 技報堂 (東京).

橋本春雄, 1941 虫に於ける連関の研究. 奛試報告 10:327-346.

市川信一，1943 新重「い」形亘の遗伝と異常肧子に就いて。 I . 遗伝学雑誌 19: 182-188.

市川信一, $1952 \mathrm{a}$ 虫の $E$ 複対立遺层子群に関する遺伝学的並に発生学的研究. 虫試報告 14:23-91.

书川信一, $1952 \mathrm{~b}$ 蚠の $E$ 遺伝子群内の交文. 遺伝学雑誌 27：231.

俅川信一, 1957 カイコの $E$ 偽対立遺伝子群に関する研究, 虫系研究 23: 18-20.

佐々术 静, 1930 過剩肢亘の遺伝学的研究. 日本亘系学雑誌 1: 87-102.

鈴木簡一郎・太田慎一郎, 1930 重「い」形矤の遺伝. 遺伝学雑誌 6: 3-13.

高崎恒雄, $1952 E$ 複対让遺层子群, 家虫遺伀学: 487-511, 裳華房 (東京).

辻田光雄, 1955 カイコの $E$ 遺伝子群中の $E^{H}$ と $E^{K p}$ との交文について, 遺伀学雑誌 $30: 227-235$.

辻田光雄・坂口文吾, $1959 \mathrm{a}$ 作用的に関連した複合座位, 遺伝研年報 9: 68-69.

辻田光雄・坂口文吾, $1959 \mathrm{~b}$ 複合座位構成遗伝子開の相互作用一一カイコにおけるE複合座位の場合. 笑験形 態学新説：283-291，養賢堂(東京). 